\section{Effects of Pruning and Cropping on Field-grown Primocane-fruiting Blackberries}

\author{
Chrislyn A. Drake ${ }^{1}$ and John R. Clark ${ }^{2}$ \\ Department of Horticulture, University of Arkansas, Fayetteville, AR 72701
}

Additional index words. Rubus, cane management, small fruits, germplasm

\begin{abstract}
Primocane-fruiting blackberry (Rubus subgenus Rubus Watson) selections have recently been developed by the University of Arkansas, but proper cane-management practices for the new germplasm have not yet been determined. It was observed in previous trials that primocane-fruiting selections flowered and fruited in late July and early August in Arkansas, which is often the hottest part of the summer and earlier than desired. Therefore, this study was conducted to determine the effects of primocane tipping on cane and fruit characteristics and to determine the effect of floricane presence on primocane performance. In Fayetteville, one-year-old plants of selections APF-8 and APF-12 were used to apply the four primocane-tipping treatments in combination with the two cane management treatments (presence or absence of floricanes). In Clarksville, the same genotypes were used to apply the two cane management treatments (presence or absence of floricanes). The tipping treatments had a significant effect on primocane yield and peak harvest as well as other parameters. The cane management treatments had a significant effect on total yield, but no other effects.
\end{abstract}

In recent years, blackberries (Rubus subgenus Rubus Watson) have become a widely grown horticultural crop in Arkansas and elsewhere in the southern United States. According to Moore (1997), the first blackberry breeding program was begun by the Texas Agricultural Experiment Station in 1909. Very few blackberry breeding programs are active in the United States today, although one of the largest is at the Univ. of Arkansas. A current goal of the breeding program at the Univ. of Arkansas is to develop primocanefruiting (fall fruiting) cultivars to allow fruiting into autumn.

Currently, the primocane-fruiting trait is almost exclusively found in the raspberry subgenus (Idaeobatus Watson), most prominently in red raspberries (Rubus ideaus L.) (Moore et al., 1999). Many primocane-fruiting red raspberry cultivars such as 'Heritage' (Ourecky, 1969) are widely planted.

Lopez-Medina et al. (2000) researched the inheritance of the primocane-fruiting trait in blackberry. From his seedling populations, 13 primocane-fruiting selections were identified that displayed desirable characteristics such as good plant vigor and consistent primocane trait expression with acceptable fruit size and good flavor. However, some concerns exist regarding these primocane-fruiting selections. The primocanes fruit during late July, August, and September, when temperatures in Arkansas are

Received for publication 28 Jan. 2002. Accepted for publication 9 May 2002. Published with approval of the Director, Arkansas Agricultural Experiment station, manuscript no. 02008. We thank Kenda Woodburn for assistance in data collection. Genotypes used in this study are breeding selections and are not available in commerce at the time of publication.

${ }^{1}$ Graduate Assistant.

${ }^{2}$ Professor. often high enough to damage fruit. Examples of high temperature effects on blackberry fruit are small, crumbly berries and poor flavor. A second concern with the primocane-fruiting selections is that their primocane yields are low compared to floricane yields of floricanefruiting cultivars. We hypothesized that the practice of tipping primocanes may delay time of fruiting and increase yields.

Research in primocane-fruiting red raspberries showed that tipping primocanes has some effect on primocane period of fruiting and yield. Studies in Missouri with 'Heritage' red raspberry found that tipping primocanes at $\approx 1 \mathrm{~m}$ in height significantly delayed fruiting if a large enough portion of the cane was removed; tipping of 2 to $5 \mathrm{~cm}$ did not delay ripening while removal of $30 \mathrm{~cm}$ did (Richter et al., 1989). Tipped plants had similar yields as the control plants. In New Jersey, J. Fiola (personal communication) used two tipping treatments, a "soft tip" (removal of 2 to $5 \mathrm{~cm}$ ) and a "hard tip" (removal of 5 to $12 \mathrm{~cm}$ ) when canes reached full height, and found that "soft tip" delayed harvest $\approx 3$ weeks and the "hard tip" 5 weeks. Yield was lower for tipped plants than untipped plants due to an early frost that destroyed late-ripening berries. Researchers in New Zealand also had success in delaying the harvest period and in some cases, increasing yields, of 'Heritage' using tipping treatments (Jordan and Ince, 1986).

As primocane-fruiting blackberries can be managed in a double-cropping (a primocane and floricane crop) or a single-cropping (a primocane crop only) system, it is important to determine if a floricane crop has any effect on the primocanes. In floricane-fruiting red raspberries, studies found that competition exists between the primocanes and floricanes. Freeman et al. (1989) showed that removing early flushes of primocanes (and then allowing later flushes of primocanes to grow) increased floricane yields. Other researchers studied alternate-year production in red raspberry, where the vegetative and reproductive cycles were completely separated. Wright and Waister (1982) found that removing floricanes resulted in the production of more primocanes. Clark (1984) found that the yields in alternate-year production systems were $50 \%$ higher in the "on year" than traditional cropping systems. Some researchers felt that the increased yield in the alternate-year system was partially due to improved light interception by the vegetative and reproductive phases (Wright and Waister, 1982). However, Waister et al. (1977) also pointed out that the primocanes and floricanes may have been competing for water, minerals, or assimilates in addition to light. In alternate-year production in 'Marion' trailing blackberry, "on" year yields are $\approx 70 \%$ to $90 \%$ of an every-year system (Strik, 1992).

Because no information is available for field management of primocane-fruiting blackberries, the goal of this research was to investigate some fundamental cane management practices on the newly-developed primocane-fruiting blackberry selections. Therefore, the objectives of the study were to determine the effects of floricane presence on primocane performance, and the effect of primocane tipping on harvest period, yield, and primocane growth.

\section{Materials and Methods}

The two most promising primocane-fruiting selections, APF-8 and APF-12 (J.N. Moore, personal communication) were used for two separate studies in established plantings at two locations. The largest study was conducted in a field established in 1999 at the Arkansas Agricultural Research and Extension Center, Fayetteville [northwest Arkansas, lat. $36^{\circ} 5^{\prime} 4^{\prime} \mathrm{N}$,

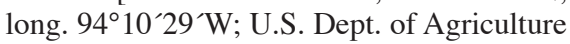
(USDA) hardiness zone 6b; soil type Captina silt loam (Typic Fragiudults)]. The planting consisted of 10 plots ( $3 \mathrm{~m}$ in length and $1 \mathrm{~m}$ in width) of each genotype arranged in a randomized incomplete-block design, with five plants in each plot. The field was irrigated and fertilized according to standard cultural practices for floricane-fruiting blackberries in Arkansas (Patterson, 1992). Weeds were controlled by use of preemergence herbicides and mechanical methods. To determine the effect of floricane cropping on primocane performance, floricanes were removed from half of the plants of each selection on 6 Mar. 2000, before growth had begun. Five randomly selected plots of each selection were pruned so that floricanes were removed from the $1^{\text {st }}, 3^{\text {rd }}$, and $5^{\text {th }}$ plants in the plot, and the other five plots were pruned so that floricanes were removed from the $2^{\text {nd }}$ and $4^{\text {th }}$ plants in the plot. Plants that retained floricanes were pruned according to standard cultural practices for floricane-fruiting blackberries, which consisted predominately of shortening laterals to $\approx 30 \mathrm{~cm}$ in length.

On the same plants, three tipping treatments and an untipped control were imposed to determine the effect of tipping on harvest period, 
yield, and primocane growth. The treatments were: 1) "soft tip" when primocanes reached 1 m tall, 2) "soft tip" at inflorescence appearance, and 3) "soft tip" 2 weeks after inflorescence appearance. "Soft tip" was defined as the removal of 2.5 to $5.0 \mathrm{~cm}$ from the distal end of the cane. Tipping treatments were applied on the following dates: tip at 1-m cane height on 2 June 2000 for APF-8 and APF-12, tip at inflorescence appearance on 27 June for APF12 and on 19 July for APF-8, tip 2 weeks after inflorescence appearance on 10 July for APF-12 and on 2 Aug. for APF-8. Floricane yield was recorded on a per plant basis; all other measurements were taken on individual primocanes and included peak harvest date, number of fruits, total yield, and average berry weight. Fruit were picked twice a week during the floricane and primocane harvest periods and were weighed immediately following harvest. Peak harvest date was determined at the end of the season by using the date that the cane produced the highest weight of fruit. Data analysis was performed with the Statistical Analysis Systems Program (SAS Inst., 1999). All responses on the primocane were analyzed with the MIXED procedure in which the fixed effects were the main effects and interactions of cane treatment, tipping treatment and genotype and the random effects were plot within genotype and plant within genotype and plot. Mean separation was by multiple $t$ tests $(P \leq 0.05)$.

A second study evaluated only the effect of floricane cropping on primocane performance, and was conducted at the Univ. of Arkansas Fruit Substation, Clarksville [west-central Arkansas, lat. $35^{\circ} 31^{\prime} 58^{\prime} \mathrm{N}$, long. $93^{\circ} 24^{\prime} 12^{\prime} \mathrm{W}$; U.S. Dept. of Agriculture (USDA) hardiness zone $7 \mathrm{a}$; soil type Linker fine sandy loam (Typic Hapludult)], where a replicated planting of APF-8 and APF-12 was established in Spring 1998. One 6-m plot and one 3-m plot each of the two selections were used, with 10 and 5 plants per plot, respectively. The field was irrigated and fertilized according to standard cultural practices for floricane-fruiting blackberries in Arkansas (Patterson, 1992). Weeds were controlled by preemergence herbicides and mechanical methods. Canes were removed from plants in the primocane-fruiting only group on 7 Mar. 2000, before growth had begun. In the $6 \mathrm{~m}$-long plots, floricanes were removed from the $2^{\text {nd }}, 4^{\text {th }}, 6^{\text {th }}, 8^{\text {th }}$, and $10^{\text {th }}$ plants, and in the $3 \mathrm{~m}$-long plots, floricanes were removed from the $2^{\text {nd }}$ and $4^{\text {th }}$ plants. Plants retaining floricanes were pruned according to standard practices for floricane-fruiting blackberries, which consisted predominately of shortening laterals to $\approx 30 \mathrm{~cm}$ in length. All measurements were recorded on a per plant basis and included floricane yield, primocane yield, primocane peak harvest date, primocane fruit number, and primocane average berry weight. Fruit were picked twice a week during the floricane and primocane harvest period, and were weighed immediately following harvest. Data analysis was performed with the Statistical Analysis Systems Program (SAS Institute, 1999). Analysis of variance (ANOVA) was calculated by the GLM procedure for the two-factor factorial of genotype $\mathrm{x}$ cane treatment; the variation among plants was the mean square error for testing.

\section{Results and Discussion}

For primocane yield and berry weight, no interactions of genotype, cane treatment, and tipping treatment were significant. However, for primocane berry number, all three of the 2-way interactions were significant. Primocane yield varied significantly among tipping treatments (Table 1). The canes tipped at $1 \mathrm{~m}$ and the untipped canes had the highest yields overall. Tipping treatment also affected primocane berry weight (Table 1). The untipped canes did not have significantly heavier berries than the canes tipped at $1 \mathrm{~m}$, but did have heavier berries than the canes tipped at inflorescence appearance and at two weeks after inflorescence appearance. Heat damage could be the cause of the low berry weight for the two late tipping treatments. During the last 2 weeks of August, when canes tipped at inflorescence appearance and at 2 weeks after inflorescence appearance were blooming, the average high temperature was $36^{\circ} \mathrm{C}$ and only a trace of rain fell. These extremely hot and dry conditions may have resulted in poor pollination, which in turn caused berries from the two late treatments to be extremely small and crumbly, while berries from canes tipped at $1 \mathrm{~m}$ and the untipped canes were usually well-sized and whole.

In Fayetteville, APF-12 had significantly higher yields than did APF-8, with 56.0 g per cane compared to $29.4 \mathrm{~g}$ (data not shown). However, APF-8 had significantly larger berries, averaging $2.1 \mathrm{~g}$ compared to $1.7 \mathrm{~g}$ for APF-12 (data not shown). This difference in berry weight could be due to a difference in berry number, as APF- 8 produced fewer berries than APF-12 (Table 2).
The double-cropping and single-cropping treatments had similar primocane yields, but primocanes in the single-crop treatment produced significantly heavier berries $(2.1 \mathrm{~g})$ than those in the double-crop treatment (1.8 g) (data not shown).

For the interaction of genotype and tipping treatment on primocane berry number, APF-12 had a higher berry number than APF-8 for the canes tipped at $1 \mathrm{~m}$ and the untipped canes (Table 2). For APF-8, canes tipped at $1 \mathrm{~m}$ had more berries than canes tipped at inflorescence appearance and canes tipped 2 weeks after inflorescence appearance, but did not have higher berry number than the untipped canes. For APF-12, the canes tipped at $1 \mathrm{~m}$ had higher berry numbers than all other treatments.

For the interaction of tipping treatment and cane treatment on primocane berry number, the primocanes tipped at $1 \mathrm{~m}$ within the double-crop treatment produced a significantly higher berry number than did the single-crop treatment (Table 2). For all other tipping treatments, there were no differences among cane treatments. For the canes in the single-crop treatment, the canes tipped at $1 \mathrm{~m}$ and the untipped canes had significantly higher berry numbers than the other treatments. For the canes in the double-crop treatment, the canes tipped at $1 \mathrm{~m}$ had significantly higher berry numbers than all other treatments and the untipped treatment had more berries than the later tipping treatments.

For the interaction of cane treatment and genotype on primocane berry number,APF-12 had significantly more berries than APF-8 for each of the cane treatments (Table 2). For APF8 , there were no differences between the cane treatments, but for APF-12, the double-crop treatment produced a significantly higher berry number than the single-crop treatment.

The better performance of APF-12 com-

Table 1. Main effect of tipping treatment on primocane yield, total yield, and berry weight of primocane-fruiting blackberries averaged over cane treatment and genotype, Fayetteville, 2000.

\begin{tabular}{lccc}
\hline Tipping & $\begin{array}{c}\text { Primocane yield } \\
\text { treatmment }\end{array}$ & $\begin{array}{c}\text { Total yield } \\
(\mathrm{g})\end{array}$ & $\begin{array}{c}\text { Primocane } \\
\text { berry wt }(\mathrm{g})\end{array}$ \\
\hline Tip at 1-m height & $77.8 \mathrm{a}^{\mathrm{z}}$ & $1003.2 \mathrm{ab}$ & $2.0 \mathrm{ab}$ \\
Tip at inflorescence & $16.9 \mathrm{~b}$ & $1092.9 \mathrm{ab}$ & $1.9 \mathrm{~b}$ \\
Tip 2 weeks after inflorescence & $9.9 \mathrm{~b}$ & $814.3 \mathrm{~b}$ & $1.6 \mathrm{~b}$ \\
Untipped control & $66.2 \mathrm{a}$ & $1263.5 \mathrm{a}$ & $2.2 \mathrm{a}$ \\
\hline
\end{tabular}

${ }^{2}$ Means in columns followed by the same letter are not significantly different by $t$ test $(P \leq 0.05)$.

Table 2. Interaction effects of genotype, tipping treatment, and cane treatment on primocane berry number of primocane fruiting blackberries, Fayetteville, 2000.

\begin{tabular}{|c|c|c|c|c|c|c|}
\hline & \multicolumn{3}{|c|}{ Genotype } & \multicolumn{3}{|c|}{ Cane treatment } \\
\hline & APF- $8^{2}$ & APF-12 & $\begin{array}{c}\text { Difference } \\
\text { between } \\
\text { genotypes }\end{array}$ & $\begin{array}{l}\text { Single } \\
\text { crop }\end{array}$ & $\begin{array}{c}\text { Double } \\
\text { crop }\end{array}$ & $\begin{array}{l}\text { Difference } \\
\text { among cane } \\
\text { treatments }\end{array}$ \\
\hline \multicolumn{7}{|l|}{ Tipping treatment } \\
\hline Tip at $1 \mathrm{~m}$ height & $24.0 \mathrm{a}^{\mathrm{y}}$ & $56.6 \mathrm{a}$ & $*$ & $27.5 \mathrm{a}$ & $53.1 \mathrm{a}$ & $*$ \\
\hline Tip at inflorescence & $6.2 \mathrm{bc}$ & $14.5 \mathrm{c}$ & NS & $5.7 \mathrm{~b}$ & $15.0 \mathrm{c}$ & NS \\
\hline Tip 2 weeks after & & & & & & \\
\hline inflorescence & $2.5 \mathrm{c}$ & $8.6 \mathrm{c}$ & NS & $2.8 \mathrm{~b}$ & $8.2 \mathrm{c}$ & NS \\
\hline Untipped treatment & $16.1 \mathrm{ab}$ & $42.2 \mathrm{~b}$ & $*$ & $29.4 \mathrm{a}$ & $29.1 \mathrm{~b}$ & NS \\
\hline \multicolumn{7}{|l|}{ Cane treatment } \\
\hline Single crop & $10.4 \mathrm{a}$ & $22.3 \mathrm{~b}$ & * & & & \\
\hline Double crop & $14.0 \mathrm{a}$ & $38.7 \mathrm{a}$ & * & & & \\
\hline
\end{tabular}

${ }^{2}$ APF-8 and APF-12 are unreleased breeding germplasm and are not available in commerce.

${ }^{y}$ Means within columns followed by the same letter are not significantly different by $t$ test $(P \leq 0.05)$. 
pared to APF-8 may be due to the primocanes of APF-12 blooming earlier on average than those of APF-8, therefore allowing it to escape much of the heat during bloom that APF-8 experienced. APF-8 had lower levels of fruit set than APF-12: $\approx 50 \%$ of the flowers produced fruit for APF-12, while only $40 \%$ of the flowers produced fruit for APF-8 (data not shown).

The lack of effect of cane treatment on primocanes was rather unexpected. Prior to this study, it was thought that the primocanes in the single-crop treatment would perform better than the primocanes in the doublecrop treatment due to the greater amount of carbohydrates that would be available because of the absence of the floricanes. This non-effect of cane treatment could be due to a lack of competition between primocanes and floricanes for carbohydrates. Fernandez and Pritts (1993) found that the floricanes and primocanes of 'Titan' floricane-fruiting raspberries do not compete for carbohydrates. Further studies reported that 'Titan' was resistant to reduction in carbon supply, which indicated that raspberries store a large amount of carbohydrate in the root system that can be used by the plant when necessary (Fernandez and Pritts, 1996). Studies by Privé et al. (1994) found that primocane-fruiting raspberries are more sink- than source-limited.

For total plant yield, which was floricane and primocane yield combined, none of the interactions were significant and of the main effects, only tipping treatment and cane treatment were significant. The main effect of tipping treatment on total plant yield showed that there was no significant difference between the canes tipped at $1 \mathrm{~m}$, the canes tipped at inflorescence, and the untipped canes (Table 1). The canes tipped two weeks after inflorescence appearance had a lower total yield than the untipped canes. The small effect of tipping treatment on total plant yield was most likely because the floricane yield of the plants was so great, therefore negating the differences in primocane yield.

The main effect of genotype on total plant yield indicated that there was no difference between APF-8 and APF-12. The highly significant effect of cane treatment on total plant yield showed the large difference between floricane yield and primocane yield as the double-crop treatment resulted in a total plant yield of $1966.2 \mathrm{~g}$, while the single-crop treatment only produced a total plant yield of $120.8 \mathrm{~g}$ (data not shown). This large difference was expected as floricanes fruited along most of the length of the cane, while primocanes fruited only at the distal end of the cane or lateral. Also, berry weight on primocanes was $\approx 2.0 \mathrm{~g}$, while average berry weight on floricanes was $5.5 \mathrm{~g}$ (data not shown). An increase this great in fruit weight could significantly affect yield.

No significant interactions were found for peak harvest date, and tipping treatment and genotype were the only main effects that were significant. For peak harvest date, the canes tipped at $1 \mathrm{~m}$ and the untipped canes were the earliest, and were only separated by $1 \mathrm{~d}$ ( 23 and 24 Aug., respectively) (data not shown) whereas the other two treatments peaked $\approx 2$ weeks later (8 and 5 Sept., respectively) (data not shown). Even though temperatures had cooled somewhat by mid-September, the two late tipping treatments were developing flowers and fruits during a period of extreme heat. While a delay in fruiting was attained by using the two late tipping treatments, fruiting characteristics were negatively impacted. The mean peak harvest date for APF-12 was significantly earlier than APF-8, with 9 d separating the two treatments (26 Aug. and 4 Sept., respectively). Cane treatment did not have a significant effect on mean peak harvest date, with only $1 \mathrm{~d}$ separating the single crop and double crop treatments (30 and 31 Aug., respectively).

For the second study (Clarksville), cane treatment (floricanes retained or not) had no effect on primocane performance overall. No interaction effects were seen, so only main effect means are discussed. All data were analyzed on a whole-plant basis.

For primocane yield, berry weight, and berry number, the main effects (genotype and cane treatment) were not significant. For total plant yield (primocane and floricane yield), cane treatment was significant, but genotype was not. The total yield of the double-crop treatment was about nine times that of the single-crop treatment (1992.3 g and $215.3 \mathrm{~g}$, respectively) (data not shown). These results were very similar to Fayetteville. A large difference in fruit size was also seen in Clarksville; primocane berries weighed $\approx 2.1 \mathrm{~g}$, while floricane berries weighed $\approx 4.5 \mathrm{~g}$ (data not shown).

Genotype had a significant effect on primocane peak harvest date but cane treatment had no effect. The peak harvest date of APF- 12 was $\approx 9$ d earlier than the peak harvest date of APF-8 (6 and 15 Aug., respectively). Nine days also separated peak harvest of the two genotypes in Fayetteville. The peak harvest dates of the single crop and double crop cane treatments were not different.

Although the presence of floricanes did not have the impact on primocane performance that was anticipated, some valuable information about the management of primocane-fruiting blackberries was learned-for example, double-cropping the plants was not detrimental to the primocane crop in the same year. However, the long-term effects of double-cropping primocane-fruiting blackberries are still unknown, and future studies could determine if any long-term effects do exist.

From the tipping treatment studies, it was learned that tipping after plants have shifted to the reproductive mode was detrimental to yield. Future studies with tipping treatments could look at the effects of severity of tipping early in the season, perhaps even before the canes have reached $1 \mathrm{~m}$ in height. Also, these genotypes may perform differently in other climates, particularly those with more moderate late summer and fall temperatures. In these climates, cane tipping to delay or extend harvest in the fall may be valuable, particularly if some method of protected culture such as "high tunnels" are used.

\section{Literature Cited}

Clark, R.J. 1984. Biennial cropping, an alternative production system for red raspberries (Rubus idaeus L.). Scientia Hort. 24:315-321.

Fernandez, G.E. and M.P. Pritts. 1993. Growth and source-sink relationships in 'Titan' red raspberry. Acta Hort. 352:151-157.

Fernandez, G.E. and M.P. Pritts. 1996. Carbon supply reduction has a minimal influence on current year's red raspberry (Rubus idaeus L.) fruit production. J. Amer. Soc. Hort. Sci. 121: 473-477.

Freeman, J.A., G.W. Eaton, T.E. Baumann, H.A. Daubeny, and A. Dale. 1989. Primocane removal enhances yield components of raspberries. J. Amer. Soc. Hort. Sci. 114:6-9.

Jordan, D. and J. Ince. 1986. Primocane tipping to programme production in fall (autumn) cropping raspberries. HortScience 21:775. (Abstr.)

Lopez-Medina, J., J.N. Moore, and R.W. McNew. 2000. A proposed model for inheritance of primocane fruiting in tetraploid erect blackberry. J. Amer. Soc. Hort. Sci. 125:217-221.

Moore, J.N. 1997. Blackberries and raspberries in the southern United States: Yesterday, today, and tomorrow. Fruit Var. J. 51:148-157.

Moore, J.N., J.R. Clark, and J. Lopez-Medina. 1999. Potential of primocane-fruiting blackberries. Proc. of the $18^{\text {th }}$ Annu. Hort. Industries Show. 11-13.

Ourecky, D.K. 1969. 'Heritage', a new fall-bearing red raspberry. Fruit Var. Hort. Dig. 23:78.

Patterson, K. 1992. Blackberry production in Arkansas. Arkansas Coop. Ext. Serv. FSA2082.

Privé, J.P., J.A. Sullivan, and J.T.A. Proctor. 1994. Carbon partitioning and translocation in primocane-fruiting red rasbperries (Rubus idaeus L.). J. Amer. Soc. Hort. Sci. 119:604-609.

Richter, R., M. Kaps, and M. Odneal. 1989. Approaches to problems with the harvest season of 'Heritage' red raspberry in Missouri or isn't a fall-bearer supposed to bear in fall? Proc. 1989 Missouri Small Fruit Conf. 26-38.

SAS Institute. 1999. SAS OnlineDoc ${ }^{\circledR}$, Version 8. SAS Inst., Cary, N.C.

Strik, B.C. 1992. Blackberry cultivars and production trends in the Pacific Northwest. Fruit Var. J. 46: 202-206.

Waister, P.D., M.R. Cormack, and W.A. Sheets. 1977. Competition between fruiting and vegetative phases in the red raspberry. J. Hort. Sci. 52:75-85.

Wright, C.J. and P.D. Waister. 1982. Within-plant competition in the red raspberry. I. Primocane growth. J. Hort. Sci. 57:437-442. 